\title{
Editorial for the Special Issue "Microwave Indices from Active and Passive Sensors for Remote Sensing Applications"
}

\author{
Simonetta Paloscia ${ }^{(D)}$ and Emanuele Santi * \\ National Research Council, Institute of Applied Physics, 50019 Florence, Italy; s.paloscia@ifac.cnr.it \\ * Correspondence: e.santi@ifac.cnr.it; Tel.: +39-055-5226431
}

Received: 16 January 2019; Accepted: 17 January 2019; Published: 7 March 2019

Keywords: Microwave Radiometry; Microwave Indices; Soil Moisture Content; Vegetation Biomass; Snow Depth and Snow Water Equivalent

Since the early 1980s, the capabilities of satellite sensors operating at microwaves for the remote sensing of Earth's surface have been widely assessed in a number of studies (e.g., [1]). Due to the high sensitivity of microwave emission and scattering to water content in the observed surfaces, microwave sensors, both active (scatterometers, SAR) and passive (radiometers), can provide useful information on the hydrological and carbon cycles, enabling the retrieval of the main soil, snow and vegetation parameters (e.g., [2,3]).

Further research demonstrated that a significant accuracy improvement could be obtained by combining data collected at different frequencies and polarizations in appropriate indices, with respect to the one achievable with single frequency/polarization observations. In particular, Microwave Indices have been successfully related to the main geophysical parameters associated to land hydrological cycle, such as soil moisture content, plant water content and snow depth or snow water equivalent (e.g., [4-6]).

The research conducted on microwave radiometry pointed out that given combinations of data acquired by satellite sensors such as SSM/I, AMSR-E and AMSR2 can be successfully related to snow and vegetation parameters. Among these indices, the Frequency Index, which is the difference between the brightness temperatures at two frequencies (i.e., Ka and Ku bands), showed a marked sensitivity to snow cover [7], while the Spectral Polarization Indices, which are obtained combining different polarizations and frequencies, were able to correctly identify relevant values of snow depths [8-11]. Moreover, the Polarization Indices, obtained at lower frequencies (i.e., $\mathrm{X}$ - and $\mathrm{C}$-bands) as the difference between the two polarizations ( $\mathrm{H}$ and $\mathrm{V}$ ), showed a significant correlation to the vegetation biomass, allowing the correction for the effects of vegetation in the retrievals of soil moisture and the retrieval of herbaceous and agricultural vegetation biomass [11].

Similar results have been obtained in the case of active sensors (i.e., SAR and scatterometers) operating at C- and X- bands; their derived indices, as the Radar Vegetation Index (RVI) [12], were proven to be highly related to vegetation structure and vegetation biomass. These indices have been largely used for correcting the effect of vegetation cover in soil moisture retrievals and in estimating the vegetation biomass [13,14].

This special issue was aimed at providing an overview of the capabilities of Microwave Indices for remote sensing applications. Besides demonstrating their sensitivity to the main parameters of soil, vegetation and snow, the special issue was focused on the use of Microwave Indices in retrieval algorithms devoted to the estimate of soil moisture, vegetation biomass and snow depth/water equivalent, at both the local and global scale. 
The obtained results sufficiently demonstrated that the synergy between observations at different frequencies and polarizations can significantly improve the capabilities of microwave sensors in observing and retrieving parameters related to the hydrological and the carbon cycles.

In particular, the studies belonging to this special issue demonstrated the capabilities of microwave derived indices for a number of applications that span from the retrieval of soil moisture based on Sentinel-1 data in wetland ecosystems [15] to the assessment of RVI as microwave metric of vegetation cover [16]. Also, the potential of Sentinel-1 cross ratio VH/VV in monitoring crop conditions was successfully evaluated [17] and the use of SAR derived vegetation descriptors for improving the soil moisture retrieval was exploited in [18], while the fusion of scatterometric and SAR data, aimed again at the soil moisture retrieval, is proposed in [19]. Finally, the synergy of Sentinel-1 and 2 in detecting grassland phenology in mountain regions is exploited in [20]. As applications devoted to snow monitoring, the co-pol. and dual-frequency ratios at $\mathrm{Ku}-, \mathrm{X}$ - and $\mathrm{C}$-bands were demonstrated to be adequately sensitive to variations in snow thickness for the Antarctic first year ice [21]. In [22], the combination of active and passive microwave acquisitions allowed characterizing the seasonal behavior of snow properties and retrieving the effective correlation length and the snow water equivalent. Finally, an overview of the potential of microwave indices obtained from multi-frequency/polarization radiometry in monitoring soil moisture, snow depth and vegetation biomass was presented in [23].

Author Contributions: The two authors contributed equally to all aspects of this editorial.

Acknowledgments: The authors would like to thank the authors who contributed to this Special Issue and to the reviewers who dedicated their time for providing the authors with valuable and constructive recommendations.

Conflicts of Interest: The authors declare no conflict of interest.

\section{References}

1. Hollinger, J.; Lo, R.; Poe, G.; Savage, R.; Pierce, J. Special Sensor Microwave/Imager User's Guide; Naval Research Laboratory: Washington, DC, USA, 1987.

2. Ulaby, F.T.; Moore, R.K.; Fung, A.K. Microwave Remote Sensing: Active and Passive, Vol. II; Addison-Wesley: Reading, MA, USA, 1982.

3. Ulaby, F.T.; Moore, R.K.; Fung, A.K. Microwave Remote Sensing: Active and Passive, Vol. III; Artech House: Nordwood, MA, USA, 1986.

4. Njoku, E.G.; Jackson, T.J.; Lakshmi, V.; Chan, T.K.; Nghiem, S.V. Soil moisture retrieval from AMSR-E. IEEE Trans. Geosci. Remote Sens. 2003, 41, 215-229. [CrossRef]

5. Chukhlantsev, A.A. Microwave Radiometry of Vegetation Canopies; Springer: Dordrecht, The Netherlands, 2006.

6. Chang, T.C.; Foster, J.L.; Hall, D.K.; Rango, A.; Hartline, B.K. Snow water equivalent estimation by microwave radiometry. Cold Reg. Sci. Technol. 1982, 5, 259-267. [CrossRef]

7. Kelly, R.; Chang, A.T.C. Development of a passive microwave global snow depth retrieval algorithm for Special Sensor Microwave Imager (SSM/I) and Advanced Microwave Scanning Radiometer-EOS (AMSR-E) data. Radio Sci. 2003, 38, 8040-8076. [CrossRef]

8. Foster, J.L.; Chang, A.T.C.; Hall, D.K. Comparison of snow mass estimates from a prototype passive microwave snow algorithm, a revised algorithm and a snow depth climatology. Remote Sens. Environ. 1997, 62, 132-142. [CrossRef]

9. Tsutsui, H.; Koike, T. Development of Snow Retrieval Algorithm Using AMSR-E for the BJ Ground-Based Station on Seasonally Frozen Ground at Low Altitude on the Tibetan Plateau. J. Meteor. Soc. Jpn. 2012, 90, 99-112. [CrossRef]

10. Paloscia, S.; Pampaloni, P. Microwave Polarization Index for Monitoring Vegetation Growth. IEEE Trans. Geosci. Remote Sens. 1988, 26, 617-621. [CrossRef]

11. Santi, E.; Pettinato, S.; Paloscia, S.; Pampaloni, P.; Macelloni, G.; Brogioni, M. An algorithm for generating soil moisture and snow depth maps from microwave spaceborne radiometers: HydroAlgo. Hydrol. Earth Syst. Sci. 2012, 16, 3659-3676. [CrossRef] 
12. Kim, Y.; Jackson, T.; Bindlish, R.; Lee, H.; Hong, S. Radar Vegetation Index for Estimating the Vegetation Water Content of Rice and Soybean. IEEE Geosci. Remote Sens. Lett. 2012, 9, 564-568. [CrossRef]

13. Paloscia, S.; Pettinato, S.; Santi, E.; Notarnicola, C.; Pasolli, L.; Reppucci, A. Soil moisture mapping using Sentinel-1 images: Algorithm and preliminary validation. Remote Sens. Environ. 2013, 134, $234-248$. [CrossRef]

14. Kim, Y.; Jackson, T.; Bindlish, R.; Hong, S.; Jung, G.; Lee, K. Retrieval of Wheat Growth Parameters With Radar Vegetation Indices. IEEE Geosci. Remote Sens. Lett. 2014, 11, 808-812. [CrossRef]

15. Dabrowska-Zielinska, K.; Musial, J.; Malinska, A.; Budzynska, M.; Gurdak, R.; Kiryla, W.; Bartold, M.; Grzybowski, P. Soil Moisture in the Biebrza Wetlands Retrieved from Sentinel-1 Imagery. Remote Sens. 2018, 10, 1979. [CrossRef]

16. Szigarski, C.; Jagdhuber, T.; Baur, M.; Thiel, C.; Parrens, M.; Wigneron, J.-P.; Piles, M.; Entekhabi, D. Analysis of the Radar Vegetation Index and Potential Improvements. Remote Sens. 2018, 10, 1776. [CrossRef]

17. Vreugdenhil, M.; Wagner, W.; Bauer-Marschallinger, B.; Pfeil, I.; Teubner, I.; Rüdiger, C.; Strauss, P. Sensitivity of Sentinel-1 Backscatter to Vegetation Dynamics: An Austrian Case Study. Remote Sens. 2018, 10, 1396. [CrossRef]

18. Li, J.; Wang, S. Using SAR-Derived Vegetation Descriptors in a Water Cloud Model to Improve Soil Moisture Retrieval. Remote Sens. 2018, 10, 1370. [CrossRef]

19. Bauer-Marschallinger, B.; Paulik, C.; Hochstöger, S.; Mistelbauer, T.; Modanesi, S.; Ciabatta, L.; Massari, C.; Brocca, L.; Wagner, W. Soil Moisture from Fusion of Scatterometer and SAR: Closing the Scale Gap with Temporal Filtering. Remote Sens. 2018, 10, 1030. [CrossRef]

20. Stendardi, L.; Karlsen, S.R.; Niedrist, G.; Gerdol, R.; Zebisch, M.; Rossi, M.; Claudia Notarnicola, C. Exploiting time series of Sentinel-1 and Sentinel-2 imagery to detect grassland phenology in mountain regions. Remote Sens. 2019, 11, 542. [CrossRef]

21. Nandan, V.; Geldsetzer, T.; Mahmud, M.; Yackel, J.; Ramjan, S. Ku-, X- and C-Band Microwave Backscatter Indices from Saline Snow Covers on Arctic First-Year Sea Ice. Remote Sens. 2017, 9, 757. [CrossRef]

22. Lemmetyinen, J.; Derksen, C.; Rott, H.; Macelloni, G.; King, J.; Schneebeli, M.; Wiesmann, A.; Leppänen, L.; Kontu, A.; Pulliainen, J. Retrieval of Effective Correlation Length and Snow Water Equivalent from Radar and Passive Microwave Measurements. Remote Sens. 2018, 10, 170. [CrossRef]

23. Paloscia, S.; Pampaloni, P.; Santi, E. Radiometric Microwave Indices for Remote Sensing of Land Surfaces. Remote Sens. 2018, 10, 1859. [CrossRef] 